\title{
ACCOUNTING IN FOREIGN COUNTRIES
}

\author{
Goncharova V., Zachepylo D. \\ Zaporizhzhya National University \\ Ukraine, 69000, Zaporozhye, Zhukovsky St. 66 \\ sintez_audit2016@ukr.net, zachepylo2909@ukr.net \\ ORCID: 0000-0001-5556-7192, ORCID: 0000-0001-5536-9495
}

Key words:

international standards, IFRS, accounting, financial and management accounting, users.
The article considers the regulatory framework of international standards and their structure. The authors analyzed concepts of "international standards" and "accounting". The focus of this study is on two types of accounting standards. The paper concentrates on stages of IFRS and their status. The activity of the IAS Board is studied. The classification of accounting standards according by their economic content is designed. The authors compare descriptions of financial and management accounting. The study concentrates on structure of national accounting standards and their division by economic content. The factors that influence accounting in different countries are outlined out and a common factor uniting all the types of accounting is highlighted. The article classifies Britain's and the United States', continental and the South American systems. The question what countries use those systems is explored. The paper pays special attention on activity of the International Accounting Standards Committee. The IFRS status and application of those are determined. The authors consider advantages of accounting and financial reports, having in mind the international standards and its basis is the empowerment of access to the international capital markets. The list of the countries that legally use International Financial Reporting Standards is identified. With an emphasis on components of the required financial reporting forms in foreign countries the implementation stages of international accounting and reporting standards in Ukraine are explored.

\section{ОБЛІК В ЗАРУБІЖНИХ КРАЇНАХ}

Гончарова В. Г.

Запорізький національний університет

Украӥна, 69000, м. Запоріжжя, вул. Жуковського 66

\begin{abstract}
Ключові слова:
міжнародні стандарти, МСФЗ, облік, фінансовий та управлінський облік, користувачі.
\end{abstract}

\begin{abstract}
У статті розглянуто нормативно правова база міжнародних стандартів та їх структура. Досліджено поняття «міжнародні стандарти» та «бухгалтерський облік». Досліджено два види стандартів обліку. Проаналізовано етапи МСФЗ та їх статус. Досліджено діяльність Ради МСБО. Проведено класифікацію облікових стандартів за їх економічним змістом. Зроблено порівняльну характеристику фінансового та управлінського обліку. Досліджено структуру національних стандартів бухгалтерського обліку та їх поділ за економічним змістом. Відокремлено фактори, які впливають на ведення бухгалтерського обліку в різних країнах та визначено спільний фактор, що об'єднує усі різновиди обліку. Проведено класифікації систем таких як англо-американська, континентальна, південно-американська та досліджено в яких країнах вони використовуються. Досліджено діяльність Комітету з Міжнародних стандартів бухгалтерського обліку. Визначено статус МСФЗ та їх застосування.
\end{abstract}

\section{Stating the Subject of the Study}

The integration to the international economics, the revitalization of Ukraine's participation of European and Euro-Atlantic processes, and foreign investment attracting to economy of our country are impossible without support of accounting and auditing experts. The development of their professional skills to refer global level needs optimal conditions to be created. The International Accounting Standards (IAS) and the International Financial Reporting Standards (IFRS) that determine general rules and processes in accounting were required to compose. Moreover, the creation of financial reporting facilitated providing users with appropriate information for management and economic decisions.

The paper aims to define the international accounting standards and financial reporting principles and to outline the differences between the accounting systems of foreign countries.

The Analysis of Recent Research and Academic Papers A lot of scholars told about studying and using foreign experience in the organization of accounting in our country. It is worth noting that the issue of foreign experience involvement and practice is the main theme of big amount 
of papers. Slyesar T. [1] was analyzed useful information for further management decisions. Dergachova V. [2] studied the globalization of interethnic economic relations in her works. Also she has described in detail the principles of International Accounting Standards and Financial Reporting and highlighted differences between global accounting systems. Barkhatov A. [3] scrutinized the accounting for foreign economic activity ussies. Golov S. [4] analyzed the basics of accounting and worked out the comments on all International Financial Reporting Standards (IFRS) taking into consideration all the shifts, additions and new standards. Gubachova O. [5] developed a comparative description of financial and management accounting and studied the structure and content of international standards.

\section{The Purpose of the Work}

This paper intends to unfold the international financial reporting standards and international accounting standards and to analyze their implementation in international economic practice.

\section{The Main Material}

Accounting is a set of elements with a certain content and form, that are merged by systematic cooperation.
Accounting represents status and flow of enterprise resources, and captures economic information about activities. Also it includes and expresses business transactions in a single monetary value [6, p. 16].

The structure of accounting unites accumulation, shift and appliance of input and initial economic data. Those shape complete and reliable information about the financial and economic activities of the entity, and create conditions necessary for economic solutions of a limited circle of actors [6, p. 20].

Those actors who use accounting information are divided into two groups: external and internal. Among external actors are investors, government bodies, suppliers, customers, lenders, government and the public, etc. Internal users include users appointed only by a head.

The accounting lies on general principles. The main feature of the international accounting is division into two separated branches (table1):

- Financial accounting is the base of balance sheet and reports. It is open.

- Management accounting is for internal use.

Table 1. - Comparative characteristics of financial and management accounting.

\begin{tabular}{|c|c|c|c|}
\hline № & Name of an attribute & Financial accounting & Management accounting \\
\hline 1 & Obligation & Required in accordance with the law & Conducted on demand of a chief \\
\hline 2 & Limitation & $\begin{array}{l}\text { Common national and international } \\
\text { accounting standards and regulations }\end{array}$ & No limits \\
\hline 3 & Use of meters & Single monetary measure & $\begin{array}{l}\text { There is no single measure (quantitative, } \\
\text { qualitative, monetary, natural) }\end{array}$ \\
\hline 4 & An object of analysis & $\begin{array}{l}\text { Financial status, money flows, liquidity } \\
\text { of the enterprise, financial results of } \\
\text { economic activity, solvency, etc. }\end{array}$ & $\begin{array}{l}\text { Material and labor resources, production } \\
\text { and non-production outlays; cost, } \\
\text { production volume, etc. }\end{array}$ \\
\hline 5 & Frequency of reporting & Year and quarter & Current information \\
\hline 6 & Focus on & Summing up & Projection \\
\hline 7 & Information sharing & Most of the material is shared & A trade secret \\
\hline 8 & $\begin{array}{l}\text { The main users of } \\
\text { information }\end{array}$ & $\begin{array}{l}\text { Investors, lenders, government officials, } \\
\text { management staff }\end{array}$ & $\begin{array}{llll}\begin{array}{l}\text { Executives of different levels of } \\
\text { enterprise }\end{array} & & & \\
\end{array}$ \\
\hline 9 & $\begin{array}{l}\text { Responsibility for the } \\
\text { accuracy of accounting }\end{array}$ & Penalties under the law & Administrative punishment \\
\hline 10 & $\begin{array}{l}\text { The degree of accuracy } \\
\text { of information }\end{array}$ & $\begin{array}{l}\text { A certain degree of accuracy in } \\
\text { accordance with legal and accounting } \\
\text { requirements }\end{array}$ & $\begin{array}{l}\text { There are certain assumptions, rough } \\
\text { estimates due to the efficiency of } \\
\text { information. The main criterion is } \\
\text { expediency }\end{array}$ \\
\hline 11 & $\begin{array}{l}\text { Basic structure of } \\
\text { information }\end{array}$ & $\begin{array}{l}\text { Common Principles and Basic Equality: } \\
\text { Assets = Equity + Liabilities }\end{array}$ & $\begin{array}{l}\text { Three principles of costing: } \\
\text { - accounting for production costs; } \\
\text { - differentiated cost accounting; } \\
\text { - cost accounting by responsibility } \\
\text { centers }\end{array}$ \\
\hline
\end{tabular}

Source: compiled by the authors, based on [4].

Financial accounting reflects the information and relevant registration of business transactions. It summarizes data in bills, develops consolidated accounting and prepares financial statements, as well as controls the use of resources during operations and provides the necessary information to external and internal entities. The main feature of financial accounting is costs that are accounted 
for only by outlay elements without calculating the cost of certain products. The company's income is also accounted for by type and by elements. Costs and revenues are compared in general and by type of activity at the end of the reporting period. The most important comparison is made within the company.

Management accounting provides information for the enterprise management for use in planning, management and control of economic activity. [9, p.12]. It is based on the needs of the firm and is not regulated by the state. This accounting unfolds the question of methods of accounting and outlay control. Management accounting employs financial accounting data relating costs and revenues. It reshuffles them in accordance with the methodology of management accounting at the enterprise.

Accounting has essential differences in various countries. However, there is a common factor that unites all types of accounting, it is double-entry transactions for accounting items.

Several types of classification can be used for international accounting systems so far. (table 2)

Table 2. Classification of accounting systems.

\begin{tabular}{|c|c|c|}
\hline System name & $\begin{array}{l}\text { A list of countries where the system } \\
\text { is widespread }\end{array}$ & Main features \\
\hline Anglo-American & $\begin{array}{l}\text { United Kingdom, USA, Ireland, } \\
\text { Netherlands, Hong Kong, Cyprus, } \\
\text { Israel, Iceland, India, Central } \\
\text { America Canada,, Australia, Mexico }\end{array}$ & $\begin{array}{l}\text { Link to equity and securities is } \\
\text { distinct: } \\
\text { - focus is put on potential investors } \\
\text { and creditors; } \\
\text { - an advanced securities market is } \\
\text { run; } \\
\text { - professional accountants are highly } \\
\text { educated; } \\
\text { - a large number of corporations is set } \\
\text { up between states }\end{array}$ \\
\hline Continental & $\begin{array}{l}\text { France, Switzerland, Sweden, } \\
\text { Belgium, Greece, Egypt, Italy, } \\
\text { Japan, Germany, Norway, Austria, } \\
\text { Portugal, etc. }\end{array}$ & $\begin{array}{l}\text { System depends on the state apparatus } \\
\text { and the banking system: } \\
\text { - it is closely connected with banks; } \\
\text { - regulation of financial accounting } \\
\text { and reporting is strict; } \\
\text { - accounting and reporting are led for } \\
\text { the benefit of external users, namely } \\
\text { for public tax management; } \\
\text { - economic situation for the future is } \\
\text { under forecast }\end{array}$ \\
\hline South American & $\begin{array}{l}\text { countries with unstable economies } \\
\text { Brazil, Ecuador, Peru, Chile, } \\
\text { Argentina, and others }\end{array}$ & $\begin{array}{l}\text { - inflation is essential; } \\
\text { - accounting is under strict } \\
\text { regulations of the state. Income of } \\
\text { firms and individuals is under control; } \\
\text { - accounting policy is clearly defined }\end{array}$ \\
\hline
\end{tabular}

Source: compiled by the authors, based on [4].

It is known that three systems more exist in the world.

1. The European countries system includes general and analytic types of accounting. The characteristic feature is a profit base of a chart of accounts. The purpose of the whole system is increasing profits.

2. The United Nations Organization (UN) system includes two types of accounting. The purpose of the system is income growth.

3. The system of the Middle East countries is the third one. The main purpose of it is influenced by religious teachings [6 p. 11].

The difference between systems of maintenance and formation of financial results made the information analysis and systematization processes more complicated. It affected badly upon decision-making in international trade and other financial markets.
A Committee on International Accounting Standards was established to harmonize financial reporting. Accounting standards are a set of rules, methods and procedures that are aimed at accounting. They include depreciation, valuation of inventories, determining the amount of taxes and their payment, accounting for exchange rate differences etc.

Two types of accounting standards exist.

- International standards are created by A Committee on International Accounting Standards. They are recommended to use.

- National standards developed for internal use in each state separately. They are given a legislative basis.

National standards differ, but their purpose and form are the same (Fig.1). 
Purpose

Field of use

Definition

Description of the essence

Providing evidences

Date of implementation

Appendixes
To express succinctly accounting problems and to describe the goal of certain standard

Highlighting the division line of a standard, emphasizing the circumstances, where it cannot be used

Concepts of the main terms found in the text of a standard are identified

The main part, that includes principles of solving the problem

The requested information that is to be explained in financial performance, notes and accounting politics is identified

A date of implementation a standard

Appendixes are optional, and may contain detailed explanations to particular items of the standard

Fig. 1. The structure of national accounting standards

Source: compiled by the authors, based on [5].

It should be noted that national accounting standards can be classified by economic content (Fig. 2)

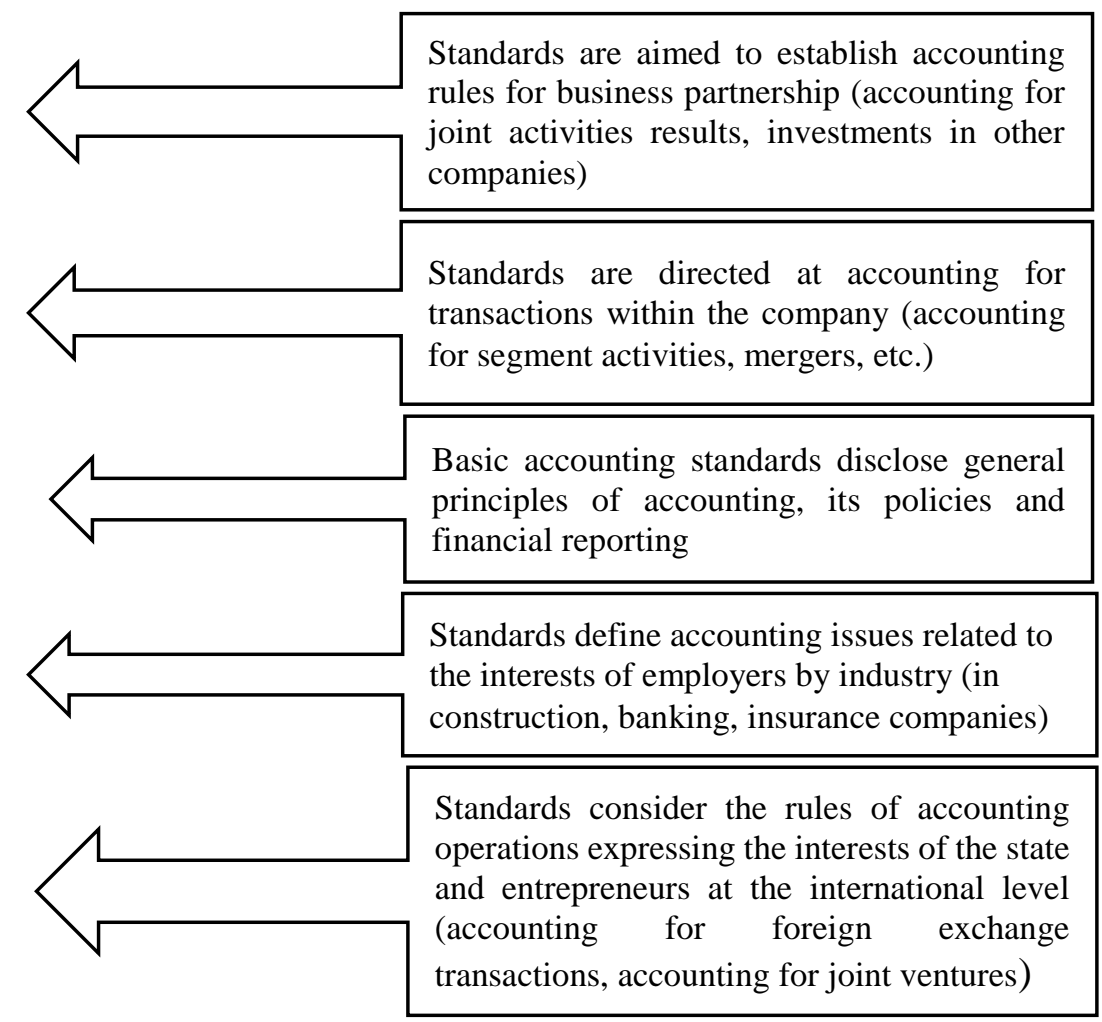

Fig. 2. Classification of standards by economic content

Source: compiled by the authors, based on [8].

On June 29, 1973, the International Accounting Standards Committee (IASC) was organized by means of a treaty between the professional organizations of accountants of Australia, Great Britain, Ireland, Canada, the Netherlands, Germany, Mexico, the United States, France, and Japan. Its function is to guarantee the financial reporting of states. And to this end, accounting standards that should be used as a norm for the financial statements in all countries have been developed, issued and updated [8].

IASC has adopted 41 international accounting standards up to 2000. 29 of those standards are currently in force. The positive and negative features of IASB are revealed in the fig. 3 . 


\begin{tabular}{|l|l|}
\hline \multicolumn{1}{|c|}{ The positive features } & \multicolumn{1}{c|}{ The negative features } \\
\hline The design is economically feasible & $\begin{array}{l}\text { Standards are generalized, as a result accounting methods } \\
\text { are imbalanced. }\end{array}$ \\
\hline World best practices are combined & $\begin{array}{l}\text { Clear explanations and examples for specific situations } \\
\text { are missing. }\end{array}$ \\
\hline A financial information is available for users & \\
\hline
\end{tabular}

Fig.3.The positive and negative features of IASB.

Source: compiled by the authors, based on [5].

The International Accounting Standards Committee (IASC) has been renamed into The International Accounting Standards Board (IASB) since 2000.

IASB develops the International Financial Reporting Standards (IFRS) since 2001. The first IFSS was approved on June 19, 2003. Eighteen international financial reporting standards currently exist.

IASB's objectives comply with the IASB Charter. They are unfolded in the list.

1. The international accounting standards piece together a single system of distinct, clear, imperative rules.

2. A strict standards compliance is promoted and guaranteed.

3. The maximum homogeneity of national accounting standards with international standards is insured [6 p. 17] [6 p. 17].

Stages of IFRS development:

1. A Steering Committee is formed with the chairman at the head.

2. The Steering Committee outlines and audits the necessary accounting issues related to the topic, then analyzes the regional and national requirements related to accounting and practice, and as a result submits a "Summary" to the Board.

3. After receiving comments from the Board, the Steering Committee prepares and publishes a "Draft Statement of Principles" for discussion. Stakeholders are involved in the argument.

4. The chair of the committee should check the comments on the "Draft Statement of Principles" and synchronize the final one. It is given to the Board to support the project and used as a basis for making ready the offered International Financial Reporting Standard [6 c.18].

Standard structure contains several elements.

1. The main thing is the object of accounting that has to be highlighted. Its basic concepts are to be adjusted to it.

2. A recognition of an accounting object is a list of criteria. It aims to add objects of accounting to various components of reporting.

3. Evaluation of the accounting object provides recommendations about usage of evaluation tools and criteria for evaluating various parts of reporting.

4. Interpretation in the financial reporting includes full information about the object of accounting in various forms of financial statements [10 p. 45].

IFRS do not have imperative meaning for accounting and reporting. Therefore, IASB's actions are aimed to improve and adapt financial statements worldwide. It can be realized through the governments and bodies arrangement to use the rules of International Accounting Standards in the preparation of financial presentations.

IFRS can be used to achieve different goals.

a) Those can present a basis for state requirements for accounting in different countries.

b) IFRS can be helping tool to establish own requirements for accounting in different countries;

c) Stock exchanges and regulatory bodies work with IFRS while requiring or authorizing foreign securities issuers to provide financial reporting documents in accordance with IAS;

d) Supranational bodies can employ IFRS (the European Commission case);

e) The World Bank turn to the international standards requiring borrowers to provide financial documentation in accordance with IFRS [8 p. 25].

The London and Frankfurt. Roman, Amsterdam, Hong Kong, Zurich stock exchanges apply the international standards.

The compliance of IFRS provides several benefits.

1. Risks for creditors and investors are reduced;

2. The costs of countries to develop their own standards are decreased;

3. The international association in the field of accounting is strengthened;

4. Financial reporting becomes more clear and as a result, trust in its elements is increased in the world.

\section{Conclusions}

Accounting is the language of communication between business participants from all over the world. It plays central role in financial management information system. Its main task is to develop a framework necessary for the analysis, interpretation and application of information. The purpose of that information is effective management decisions.

Accounting standards are the main tool for definition accounting requirements and applying them to all activities. The International Accounting Standards Committee (IASB) act for harmonizing financial reporting worldwide.

Therefore, common international standards are needed. It comes out of the following facts:

1. Investors are looking for targets to export their capital around the world.

2. Companies and enterprises try for credits with the lowest interest rates in the states.

3. Enterprises are consolidated all over the world.

4. Indicators in the financial reporting cannot be compared and analyzed totally because of the difference in systems. 
Thus, each state develops its own accounting system and reporting. Factors to influence establishment and functioning of systems are identified. The legal system is one of regulating factors that may cause essential differences in the financial statements of different countries.
Authors define that identical principles of the organization of the account in the states are missing, but all of them use the method of double documentation.

\section{References}

1. .Sliesar T. M. (2013). Osoblyvosti transformatsii bukhhalterskoho obliku v ahrarnomu sektori [Features of the transformation of accounting in the agricultural sector] Ekonomichni nauky. Cer. : Oblik i finansy. -Vyp. 10(4). S. 236-240[in Ukrainian].

2. Derhachova V V (2011) Oblik u zarubizhnykh krainakh [Accounting in foreign countries]. [in Ukrainian].

3. Barkhatov A. P. (2007) Bukhhalterskyi uchet vneshneэkonomycheskoi deiatelnosty [Accounting for foreign economic activity] [in Ukrainian].

4. Holov S. F. (2014) Futurolohiia bukhhalterskoho obliku [Futurology of accounting] Visnyk Natsionalnoho universytetu "Lvivska politekhnika". Menedzhment ta pidpryiemnytstvo v Ukraini: etapy stanovlennia i problemy rozvytku.

5. Hubachova O.M (2008) Oblik u zarubizhnykh krainakh [Accounting in foreign countries].

6. Derhachova V.V. (2011). Oblik u zarubizhnykh krainakh [Accounting in foreign countries] K.: NTUU «KPI», s 257.

7. Butynets, F. F. (2002) Bukhhalterskyi Oblik u zarubizhnykh krainakh [Accounting in foreign countries] Horetska; Zhytomyrskyi inzhenernotekhnolohichnyi instytut. Zhytomyr: Ruta.

8. Stukov, S. A. (1998) Mezhdunarodnaia standartyzatsyia y harmonyzatsyia ucheta y otchetnosty [International standardization and harmonization of accounting and reporting: textbook. Allowance] ucheb. posobye. M.: Bukhhalterskyi uchet. s. 136. [in Ukrainian].

9. Rakhubovskoho A.D. (2007) Upravlencheskyi uchet / Эntony A. Atkynson, Radzhyv D. Banker, Robert S. Kaplan, Mark S. Yanh [Management Accounting / Anthony A. Atkinson, Rajiv D. Banker, Robert S. Kaplan, Mark S. Young] 3-e yzd. M.: Vyliams. [in Ukrainian].

10. Yakovliev Yu.P. (2008) Kontrolinh na bazi informatsiinykh tekhnolohii [Controlling on the basis of information technologies: textbook. way. for students. econ. special higher textbook lock ] K.: Kondor. [in Ukrainian]. 